\title{
HYDROGEOCHEMISTRY AND GROUNDWATER QUALITY ASSESSMENT IN AZINTAN, NORTHWESTERN LIBYA
}

\author{
Ali Ben sera \\ Department of geological and environmental sciences, \\ Faculty of Sciences, University of Azintan, Libya.
}

\begin{abstract}
The groundwater aquifers in Azintan, northwestern Libya suffer from an acute shortage of water. The groundwater was evaluated to determine its suitability for drinking and irrigation purposes from major two aquifers in north and south of Azintan area. This study carried out to assess the groundwater quality and to identify major affecting variables. Twelve samples from the two aquifers were collected. The two aquifers were collected and analyzed for total dissolved solid (TDS), electrical conductivity (EC), $\mathrm{pH}, \mathrm{Ca}^{2+}, \mathrm{Mg}^{2+}$, $\mathrm{Na}^{+}, \mathrm{K}^{+}, \mathrm{Cl}^{-}, \mathrm{SO}^{2-}, \mathrm{CO}^{2-}$ and $\mathrm{HCO3}^{-}$. The results show that, the groundwater in many places is dominated by higher concentrations of $\mathrm{Cl}^{-}, \mathrm{SO}^{2-}$ and $\mathrm{HCO3}^{-}$. Two water types were recognized in this region are $\mathrm{Cl}-\mathrm{SO} 4-$ $\mathrm{Na}-\mathrm{Ca}$ and Cl-SO4-Na. Gibbs and Piper method, as well as the hardness, soluble sodium percentage and the permeability index all have been used to assess the diagram quality of the groundwater of aquifers. Further, the multiple correlations and Cluster Analysis of groundwater quality parameters were carried out for further classification and interpretation of the groundwater quality. Finally, water qualities in the study area are compared with Libyan standards and WHO guidelines of drinking water and irrigation purposes.
\end{abstract}

Keywords: (Cluster Analysis, Groundwater quality, hydrogeochemistry, Irrigation, Zintan).

\section{INTRODUCTION}

Libya's area of $1,750,00 \mathrm{sq} \mathrm{km}$ is mostly desert. Only about 4 percent of Libya's area has both sufficient rainfall and adequate soil to be considerable. Most agricultural and other human use of water are dependent on groundwater. Only two regions of the country, the Jifarah-Jabal Nafusah region (study area) and Al Jabal Al Akhdar region, receive sufficient amount of rainfall in most years to provide significant recharge to groundwater. The area investigated was the subject of numerous geological studies carried out by different geologists [19]; [8]; [12]; [24] The suitability of irrigation water depends upon many factors including the quality of water, soil type, salt tolerance characteristics of plants, climate and drainage characteristics of soil [10]; [16]. This study focused on the quality of water resources in an area that suffers from a severe shortage of water sources. The groundwater is the only source of water supply for most of the local demand (agricultural, industry, and domestic), as well as drinking and irrigation purposes. Azintan depends heavily on groundwater, which accounts for more than $97 \%$ of the water used ( $83 \%$ of agricultural holdings and $14 \%$ of household). There are no available water supply systems in the area. The only source for recharging groundwater aquifers is rainwater, which falls only in the winter season in December and January in limited quantities. Precipitation has an average annual rainfall of $150 \mathrm{~mm}$ per year. Libya has no rivers, and its surface run-off is limited to short floods following extreme rainstorms in the winter. This puts the total contribution of surface water at less than $3 \%$ of the existing water in use. Renewable basins are found in the north (Jifarah Plain, Jabal al-Akhdar and part of Hamada alHamra), while the other sedimentary basins (Murzuk, Kufra and Sarir) containing non-renewable groundwater. Renewable groundwater is estimated to be 600-650 $\mathrm{MCM} / \mathrm{yr}$. [7]. Other places that have local recharge because of rare heavy rain producing run-off have been observed in the Haruj Mountains in the centre of the country, at the Tibesti Mountains in the south and the Aweinat Mountains in the west. The recharge amount in these areas is minor and has little value compared to the storage values and aquifer losses [9]. Surface water in Jifarah plain, $170 \mathrm{MCM} / \mathrm{yr}$. collected from seasonal run-off water from dams [9]. Sustainable groundwater abstraction should not exceed 3,650 MCM/yr. [9]. This amount covers renewable groundwater in Libya is $650 \mathrm{MCM} / \mathrm{yr}$.; $25 \mathrm{MCM} / \mathrm{yr}$. Hydrochemical studies of groundwater provide a better understanding of possible changes in quality [17]. The 


\section{International Journal of Engineering Applied Sciences and Technology, 2021 \\ Vol. 6, Issue 5, ISSN No. 2455-2143, Pages 299-304 \\ Published Online September 2021 in IJEAST (http://www.ijeast.com)}

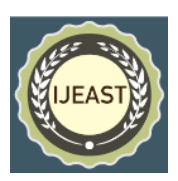

chemical parameters of groundwater play a significant role in assessing water quality, which is suitable for drinking, agriculture and industrial purposes [15]; [32] ; [4] [29] Irrigation with poor quality water may bring undesirable elements to soil in excessive quantities affecting its fertility. The quality of groundwater has definite command over the yield of crops through its effect on environment. The main objectives of this study are to analyze the characteristics and assess the quality of the groundwater from aquifers using geochemical analysis and classifications to evaluate its suitability for drinking and irrigation purposes. The empirical classification has been adopted to indicate the nature and quality of the groundwater and determine the groundwater quality of Azintan's aquifers and delineate groundwater wells.

\section{GEOGRAPHIC AND HYDROGEOLOGICAL SETTING}

Groundwater in the study area is important resource for drinking water, agricultural, domestic and industrial purposes. The hydrogeochemistry and quality of groundwater in the study area are poorly understood and have not been investigated at depth. The study area lies between $31^{\circ} 51^{\prime} 54^{\prime \prime}-32^{\circ} 55^{\prime} 50^{\prime \prime} \mathrm{N} 10^{\circ} 47^{\prime} 36^{\prime \prime}-12^{\circ} 14^{\prime} 54^{\prime \prime} \mathrm{E}$ and covers an area of approximately $50 \mathrm{~km}^{2}$. Azintan is one of the biggest cities in north western Libya in Jabal Nafusah, situated roughly 160 kilometers southwest of Tripoli. It is a rocky plateau, 600 to $700 \mathrm{~m}$ in its highest part, with a steep north face overlooking Jifarah Plain (Fig.1a) and gentle south slope ending along the northern edge of Al Hamadah Al Hamra. It has alluvial terraces, gently rolling hills and dry wadies (Fig. 1a). The average annual rainfall ranges from 100 to $250 \mathrm{~mm}$ per year, rainfall covers only the southern and eastern slopes of Jabal Nafusah [22]. The age of the outcropped rocks along Jabal Nafusah escarpment range from Jurassic to recent [12] (Fig.1b). The study area consists the Lower to Upper Cretaceous succession, has been divided into three major lithostratigraphic units ( Nalut Formation; massive and crystalline dolomitic limestone and dolomite, Sidi As Sid Formation; has been divided into two Members: Ain Tobi and Yefren Marl, it consists dolomite and marl and Kikla Formation; includes sandstone).However, the study area is underlain by the alluvial deposit, which consists of sand and gravel. The thicknesses of the alluvial deposits range from $15 \mathrm{~m}$ to more than $50 \mathrm{~m}$ and are underlain by Mesozoic sandstone and limestone as bedrock (Fig 2).The major part of the study area, located in the Jifarah plain, which rises above sea level along the coast to $200 \mathrm{~m}$ at the foot of the Jabal Nafusah escarpment. The Jifarah plain is a triangular area of about
$20000 \mathrm{~km}^{2}$, bounded on the north by the Mediterranean coast, on the south by Jabal Nafusah and on the west by the Tunisian border (Fig.1b). It is the most important part of the country for economic production and is one of the most intense areas for agricultural production in Libya. The Mesozoic sandstone rocks belong to the Kikla Formation, that are considered as one of the most potential groundwater reservoirs in Azintan.

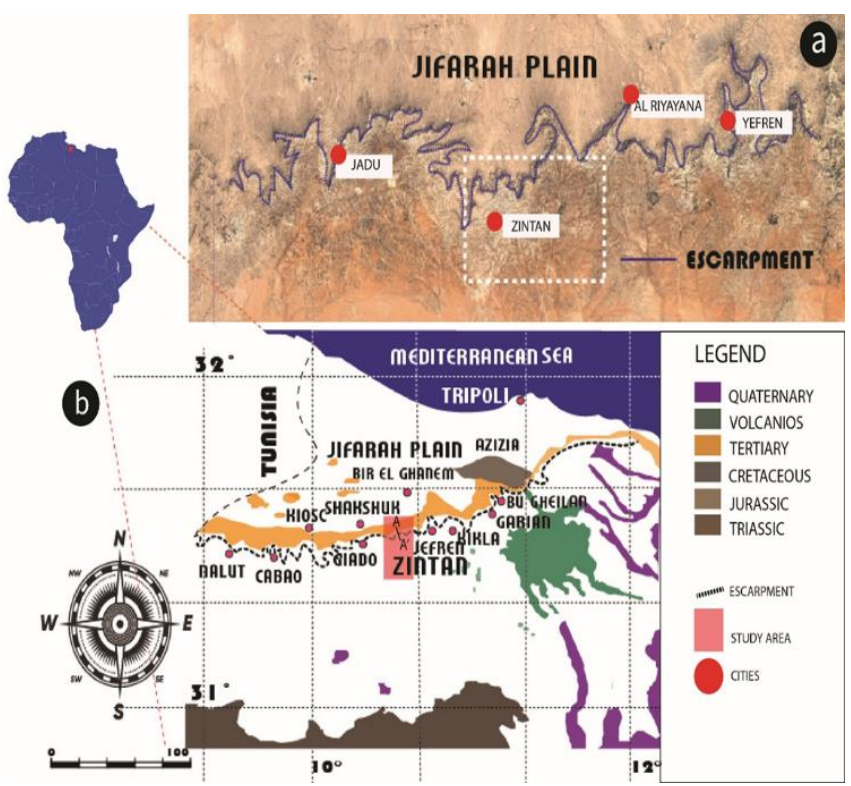

Fig.1 a. General location of Azintan area, and b. The geological map of study area (modified after [12]

The exploitable thickness of the undifferentiated formations is estimated to be around $50-100 \mathrm{~m}$. The stratigraphic superposition in the area is illustrated by the north-south cross-sectional diagram (Fig.2). The Mesozoic sandstone Formation is widely distributed through this area and the undifferentiated Mesozoic sandstone strata overlain by the limestone rocks in the south direction (Fig.2). The rainfall varies between an average of approximately 100 to 200 $\mathrm{mm} /$ year in north of the Jifarah plain. There are few resources in the studied area. precipitation (Fig.3). The study area has an average of water levels within 100-200 m below surface. 


\section{International Journal of Engineering Applied Sciences and Technology, 2021 \\ Vol. 6, Issue 5, ISSN No. 2455-2143, Pages 299-304 \\ Published Online September 2021 in IJEAST (http://www.ijeast.com)}

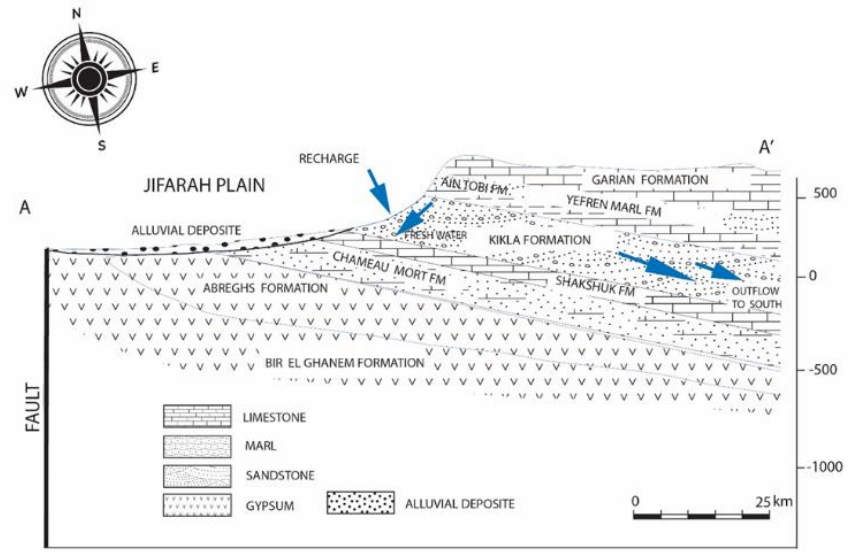

Fig. 2 Hydro cross section of A-A'. After [12]

The climatic factors of the study area are characterized by highly temperatures and high evaporation in the summer. The lowest and highest temperatures are usually observed in January and July, respectively (Fig.4). According to the data obtained from Azintan (weather station 2018), the average temperature is $17^{\circ} \mathrm{C}$ in the area. A part of the precipitation falling on the hills surrounding the Jifarah plain reaches the area surface runoff through many wadies, the length of which does not usually exceed a few kilometers. The loose sediments have been deposited in the area forming good water-bearing source. The major aquifers occur in north of Azintan city. The groundwater flow of the Azintan's aquifers covers extends south to north (S-N) direction (Fig.5).

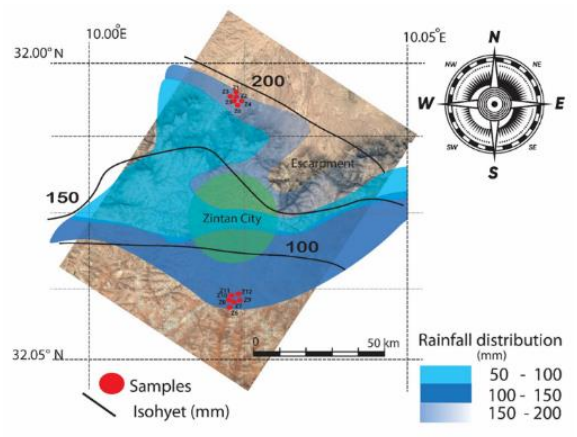

Fig.3 Rainfall distribution and water level of the study area. [22].

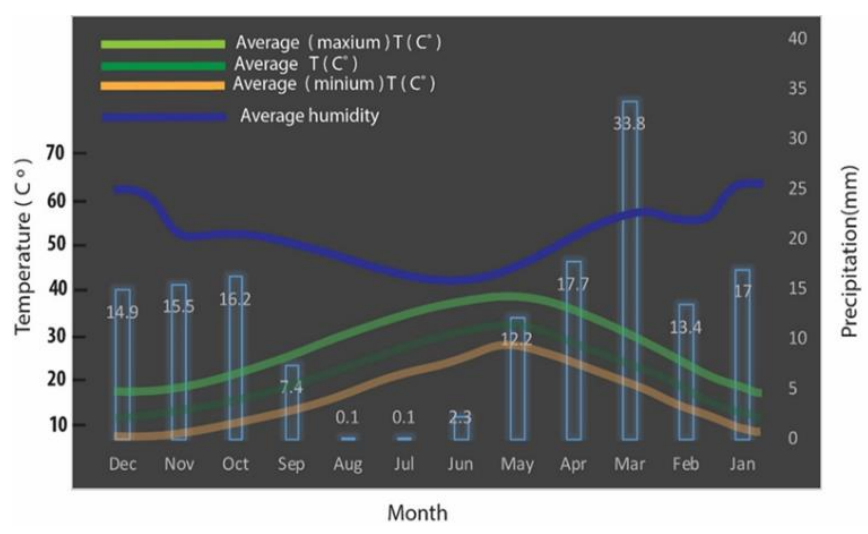

Fig. 4 Monthly average temperatures and rainfall in the study area (Azintan weather station 2020).

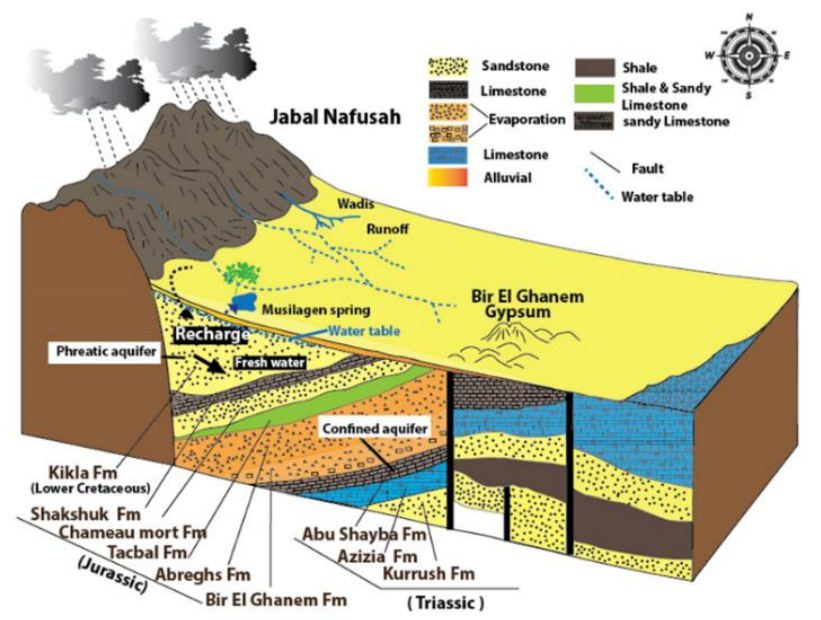

Fig. 5 Conceptual model of the groundwater system at Azintan. Modified after [18]

The hydrogeological investigation indicates that there are three major aquifers throughout the area; the Kikla, Shakshuk and Chameau Mort. The stratigraphic section refers that Kikla Formation is lying at the top of the aquiferous Cretaceous Formation. Kikla Formation is one of the most potential groundwater reservoirs in the eastern part of Jabal Nafusah [18] and is tapped for the domestic water supply of Azintan. The Kikla Formation consists of Mesozoic sandstone (Fig.2) and is overlain by the rocks of the Sidi as Sid Formation (Ain Tobi Limestone and Yefren Marls members) and Garian Limestone. The depth of the water table varies between 50 to $100 \mathrm{~m}$. The recharge of the Kikla aquifer is through infiltration of rainfall and wadi runoff. The transmissivity y $(\mathrm{T})$ of the aquifer is $2-6 \times 10^{2}$ $\mathrm{m}^{2} / \mathrm{s}$. The other major aquifer is Shakshuka Formation, 


\section{International Journal of Engineering Applied Sciences and Technology, 2021 \\ Vol. 6, Issue 5, ISSN No. 2455-2143, Pages 299-304 \\ Published Online September 2021 in IJEAST (http://www.ijeast.com)}

which is overlined by Kikla Formation, $80-110$ m thick, which consists of variegated clay, limestone, dolomite and sand. This Formation shows good permeability, The transmissivity $\mathrm{T}=2 \times 10^{3} \mathrm{~m}^{2} / \mathrm{s}$, TDS: $2000 \mathrm{mg} / \mathrm{L}$. Also, Chameau Mort Formation, 110-160 m thick, contains the main aquifer of the Jurassic group and consists of stondstone, and dolomite, which is alternated with clay. Its transmissivity values vary from $2 \times 10-3$ to $5 \times 10^{3} \mathrm{~m}^{2} / \mathrm{s}$ [18]. However, the Tacbal Formation shows a wide variety of permeability, the water quality is poor as total dissolved solids TDS> $2500 \mathrm{mg} / \mathrm{L}$ and becomes worse towards the bottom because of the increasing gypsum layers. Some 10 $000 \mathrm{~km}^{2}$ of the Jifarah overlies a system of freshwater aquifers. It can be assumed that the average rainfall is 200 $\mathrm{mm} /$ year. The overall volume falling on that area is about $200 \times 106 \mathrm{~m}^{3}$. It is generally admitted that $10 \%$ of the rainfall percolates to the water table and recharges the unconfined aquifer [18]. Hence, the recharge of the freshwater aquifer system is some $200 \times 106 \mathrm{~m}^{3}$ and the rest are evaportranspirated throughout the year.

\section{MATERIALS AND METHODS}

\subsection{Sampling and analytical procedures}

A total of 12 groundwater samples were collected from north and south of Azintan city.The north aquifer consists Lower Cretaceous sandstones (Kikla Formation), however, the south aquifer consists of hundreds of meters of Upper Cretaceous limestone. The samples were chosen carefully in order to evaluate the quality of groundwater in the study area. Major of the samples are located in the northern part of the study region, and the other samples were collected from the southern part. The samples were collected after removing the stagnant water.All groundwater samples were collected from hand-pumped wells. All groundwater samples were stored at approximately $5^{\circ} \mathrm{C}$. The groundwater samples were analyzed at the water and gas analysis laboratory of Libyan National Oil Corporation in Az Zawiya and at the Engineering faculty lab in Sabratha. The research methods of collecting groundwater samples as well as the analysis of the water sample, followed standard procedure. The $\mathrm{Ca}^{2+}, \mathrm{Mg}^{2+}, \mathrm{K}^{+}$and $\mathrm{Na}^{+}$were analyzed using flame atomic absorption spectroscopy FAAS. $\mathrm{HCO}^{-}$and $\mathrm{CO}^{-}$were determined using acid titration method. $\mathrm{Cl}^{-}$concentration was measured by $\mathrm{AgNO} 3$ titration method, while $\mathrm{SO}^{2-}$ measured by Slaver 4 method HACH.

\section{RESULTS AND DISCUSSION}

\subsection{Hydrochemical modelling and charac-teristics.}

Interaction between water and surrounding rocks and soil is considered to be the main process controlling the observed chemical characteristics. The deviation of water from equilibrium with respect to dissolved minerals is quantitatively described as follows.

\subsubsection{Saturation index (SI)}

The calculation results of SI are listed in Table 1. calculated according to the formula; saturation Index $=\lg 10(\mathrm{IAK} / \mathrm{K}$ ), Where IAK is Ion Activity Product of dissociated chemical species in solution. $\mathrm{K}$ is equilibrium constant product of chemical involved [1]. The hydrogeochemical equilibrium phases, [25] were used to calculate the SI of water with respect to the main mineral phases by phreeqc software. The SI values of calcite, dolomite and gypsum for most groundwater samples are greater than zero, indicating supersaturation of these sulfate and carbonate minerals. Equilibrium is taken to be between $\mathrm{SI}=-0.1$ to 0.1 [2]. Using saturation index approach, it is possible to predict the reactive mineralogy of the subsurface.

(Table 1) Calculated saturation indices of calcite, gypsum and dolomite

\begin{tabular}{lcc}
\hline Calcite & Gypsum & Dolomite \\
\hline SI & SI & SI \\
0.86 & 1.38 & 0.83 \\
0.56 & 1.30 & 0.60 \\
0.41 & 1.20 & 0.47 \\
0.514 & 1.00 & 0.38 \\
0.59 & 1.14 & 0.46 \\
0.84 & 1.45 & 0.72 \\
0.63 & 1.33 & 0.54 \\
0.85 & 1.45 & 0.76 \\
0.31 & 1.11 & 0.49 \\
0.84 & 1.33 & 0.83 \\
0.70 & 1.20 & 0.65 \\
0.81 & 1.15 & 0.83 \\
\hline
\end{tabular}

In the recharge zones, groundwater is gypsum-saturated, dolomite and calcite in the up gradient areas of a regional flow, due the interactions with sufficient mineral and ionic sources. This interaction will be taken place, and reach equilibrium with these minerals. Due to progressive mineral 


\section{International Journal of Engineering Applied Sciences and Technology, 2021 \\ Vol. 6, Issue 5, ISSN No. 2455-2143, Pages 299-304 \\ Published Online September 2021 in IJEAST (http://www.ijeast.com)}

dissolution the TDS in groundwater will also increase along the groundwater flow path. Therefore, the plot of TDS versus SI (Fig. 6) suggests the evolution along the flow path. The SI values of calcite and dolomite range from 0.31 to 0.86 and from 0.38 to 0.83 , respectively. The correlations between them and the TDS are not significant (Fig.6), which indicate that calcite and dolomite (carbonate minerals) do not continue to dissolve along the flow path. In contrast, the SI value of gypsum is more than one, and all minerals exhibit positive correlations with TDS (Fig. 6), which suggests that the SI values for aragonite, calcite, dolomite and most magnesite were greater than zero. Thus, water is supersaturated with precipitation of calcite, dolomite or gypsum. The $\mathrm{Ca} 2+$ will increase in groundwater due to dissolution of gypsum, which will in turn increase the SI values of calcite and dolomite. The decrease in the SI values of calcite and dolomite may support this inference (Fig. 6).

\subsubsection{Sodium Adsorption Ratio (SAR)}

The soluble sodium percentage $(\mathrm{Na} \%)$ and the Sodium Adsorption Ratio (SAR) are used for determining the suitability of groundwater for agricultural uses. However, medical research restricts sodium content in drinking water to $120 \mathrm{mg} / 1$ [5]. Both are considered a useful indicator in determining the suitability of groundwater for agricultural uses. In this study, the values of SAR and EC were plotted on salinity diagram (Fig. 7) combining the two hazards, sodium and salinity, the results show that most groundwater samples belong to the category C3-S1 (low sodium and high salinity). Theoretically, can be used with caution for agricultural purposes. Z-1, Z-10, Z-11 and Z-12 belong to C4-S2, indicate that although these samples represent low alkalinity hazard, and they are not suitable for irrigation under ordinary conditions because they represent a very high-salinity hazard. In this study area, all samples are not exceeding the limit, which may affect consumers. Depending on Libyan standard [21], it was found out that some groundwater samples were suitable for drinking; as soluble ions not exceed the maximum permissible limit. Exceed salinity reduces the osmotic activity of plants and interferes with the absorption of water and nutrients from soil (Saleh and Shehata, 1999). Salinity, Sodium absorption ratio (SAR) and sodium percentage $(\mathrm{Na} \%)$ are important parameters for determining the suitability of groundwater for irrigation uses [30]. Sodium concentration is a $n$ important factor in classifying irrigation water, because sodium reacts with soil to reduce its permeability. All ionic concentrations are expressed in milli-equivalents per liter (meq/L).Generally, when $\mathrm{Na} \%$ value is less than $60 \%$, it is acceptable for irrigation. Most of samples are plotted in zones of excellent to good, good to permissible and unsuitable zone [37]. The Sodium percentage is computed with respect to the relative proportions of cations present in water, where the concentration of ions is expressed in meq/L using formula after [23].
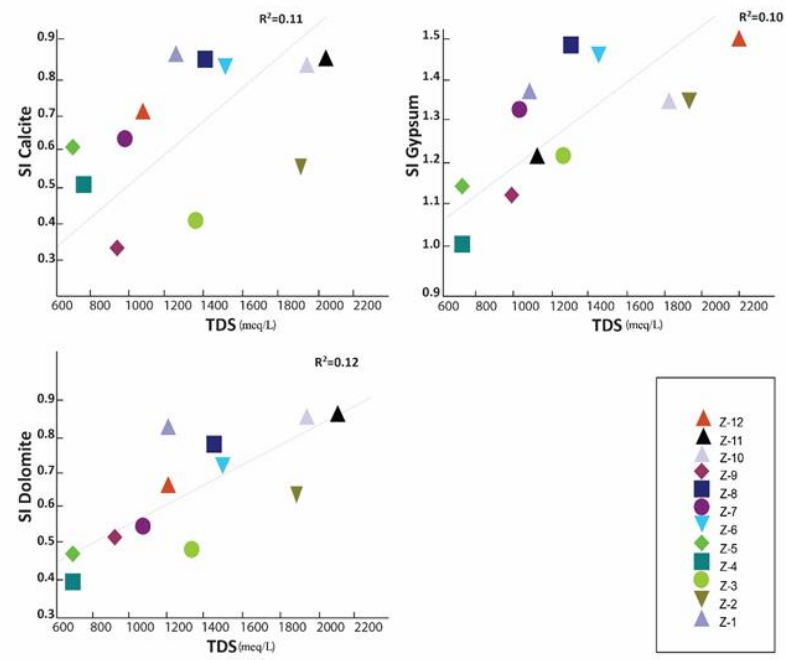

Fig. 6: Plot of SI of Calcite, Gypsum and Dolomite minerals versus TDS (meq/L).

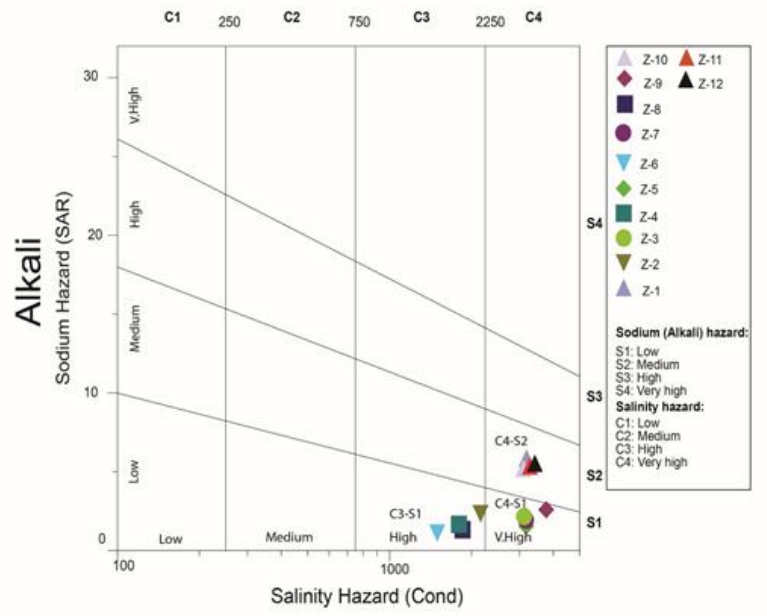

Fig. 7 Classification of groundwater, based on Salinity and Sodium Adsorption (SAR), [33]. Samples belong to the category C3-S1 (low sodium and high salinity), C4-S1 ( 


\section{International Journal of Engineering Applied Sciences and Technology, 2021 \\ Vol. 6, Issue 5, ISSN No. 2455-2143, Pages 299-304 \\ Published Online September 2021 in IJEAST (http://www.ijeast.com)}

low sodium and very high salinity) and C4-S2 ( very high salinity with medium sodium).

Samples Z-1, Z-2, Z-10 and Z-12 belong to unsuitable category (Fig. 8), indicating that they are not suitable for irrigation. The classification of groundwater samples with respect to sodium percentage are shown in (Table 2). Only four samples have values ranging between 23 to $29 \%$, which indicate values larger than or equal to $20 \%$, whereas eight samples have values ranging between 30 and $55 \%$. Most values generally less than $60 \%$, indicating that they are all safe to be used for irrigation purposes. Exceed $\mathrm{Na}+$ combining with carbonate lead to formation of alkali soil, whereas with chloride, saline soils are formed [27]. According to classification of hardness [29] and (Table 2), all samples fall under very hard water category. The chemical analysis revealed that the total hardness of CaCO3 varied from 500 to $1140 \mathrm{mg} / \mathrm{l}$ for both samples, indicating very hard water (Fig.9). The hard water noticed in most of the samples, could be attributed to calcareous soil and limestone units found in the study area. The $\mathrm{Ca} 2+$ salt in most of the groundwater samples suggests a calcareous aquifer. The plot of total hardness $(\mathrm{TH})$ versus total dissolved solids (TDS) (Fig.9a) shows that the groundwater samples lie in brackish zones to the fresh, indicating different quality levels. However, the other samples are too hard (Fig.9b). To detect mechanisms that control the hydrochemical components in surface water and groundwater, Gibbs diagram is used (Gibbs 1970). The total dissolved solids are plotted against ratios of cations $\left[\mathrm{Na}^{+} /\left(\mathrm{Na}^{+}+\mathrm{Ca}^{2+}\right)\right]$ or anions $\left[\mathrm{Cl}^{-} /\left(\mathrm{Cl}^{-}+\mathrm{HCO}^{-}\right)\right]$. The diagram is divided into three zones representing different controlling mechanisms which are evaporation, rock, and precipitation (rainfall) dominance. Gibbs diagram (Fig.9) shows that all the water samples fall entirely in the zone between the evaporation and rock dominance zone which is compatible with storage conditions. The TDS increase in irrigation water affects soil efficiency and growth and yield of plants. For long term irrigation under average conditions, the total dissolved solids should not exceed $2000 \mathrm{mg} / \mathrm{l}$. High increase in water salinity increases salts amount in soil and leads to salinization problem. Classification of water according to hardness [29] is given in Table 3.

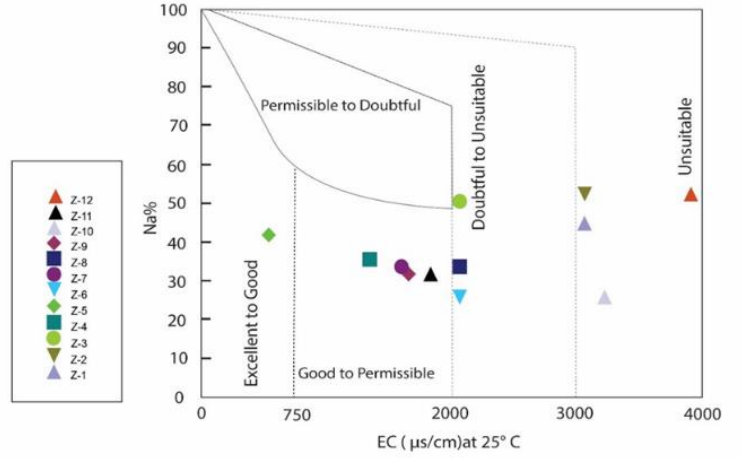

Fig. 8 Plot of $\mathrm{Na} \%$ versus EC, (Wilcox, 1948)

Table 2. Classification of groundwater, based on Sodium percentage after [37]

\begin{tabular}{lll}
\hline $\begin{array}{l}\text { Sodium } \\
(\%)\end{array}$ & Water & Samples \\
\hline$<20$ & Excellent to good & Z-9 \\
$20-40$ & Good & to \\
& permissible & \\
$40-60$ & Permissible & \\
$60-80$ & Doubtful Z-9, Z-11 & Z-6, Z-8, Z-3 \\
$>80$ & Unsuitable & Z-1,Z-2,Z-10,Z-12 \\
\hline
\end{tabular}
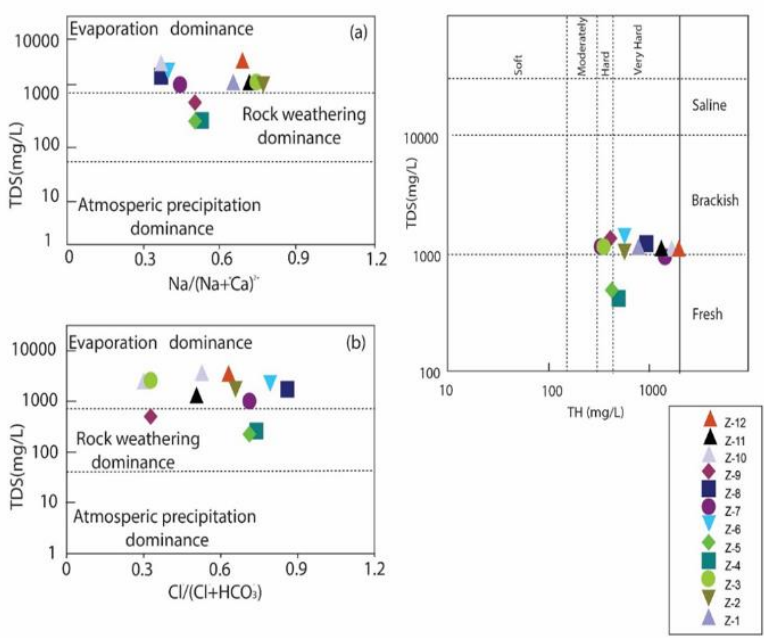

Fig.9: a) Plot of TDS versus TH expressed in $\mathrm{mg} / \mathrm{L}$ as CaCO3. b) Gibbs diagram shows TDS versus $\mathrm{Cl}^{-} /\left(\mathrm{Cl}^{-}+\right.$ $\left.\mathrm{HCO}^{-}\right)$and $\mathrm{Na}^{+} /\left(\mathrm{Na}^{+}+\mathrm{Ca}^{2+}\right)$. 


\section{International Journal of Engineering Applied Sciences and Technology, 2021 \\ Vol. 6, Issue 5, ISSN No. 2455-2143, Pages 299-304 \\ Published Online September 2021 in IJEAST (http://www.ijeast.com)}

Table 3. Classification of water based on hardness after [29]

\begin{tabular}{|c|c|c|c|}
\hline $\begin{array}{l}\text { Hardness } \\
\mathrm{CaCO}_{3}\end{array}$ & as & Water class & \\
\hline $0-75$ & & Soft & \\
\hline $75-150$ & & $\begin{array}{l}\text { Moderate } \\
\text { Hard }\end{array}$ & \\
\hline $150-300$ & & Hard & Z-3,Z-7 and Z-9 \\
\hline$>300$ & & Very hard & $\begin{array}{l}\text { The rest of the } \\
\text { samples }\end{array}$ \\
\hline
\end{tabular}

\section{RESULTS}

The analytical results of the physiochemical and the statistical analysis indices are shown in Table 4\&5. The TDS in the groundwater ranges from 676 to $2240 \mathrm{mg} / \mathrm{L}$, indicating fresh to brackish mineralized water (TDS < $3000 \mathrm{mg} / \mathrm{L}$; Aral and Warren 2001). The EC of the groundwater is higher than that of the surface water, suggesting mineral dissolution in the groundwater, EC ranges from (965 to $3730 \mu \mathrm{s} / \mathrm{cm}$ ).

All samples fall under low saline water (Banks and Siewers, 2001). Among the mean ion concentrations, the main anions are $\mathrm{SO}^{2-}$ and $\mathrm{Cl}^{-}$with averages of 345.80 and $418.917 \mathrm{mg} / \mathrm{L}$, respectively. The $\mathrm{HCO}^{-}$ranges from 191 to $502 \mathrm{mg} / \mathrm{L}$. The main cations are $\mathrm{Na}^{+}$and $\mathrm{Ca}^{2+}$ with averages of 171.198 and $124.156 \mathrm{mg} / \mathrm{L}$, respectively. The $\mathrm{pH}$ of the groundwater is within the range of 7.4 to 8.3, indicating an alkalescent tendency. All samples are compared to Libyan and WHO guidelines see Table (4). The groundwater samples have low value of total dissolved solids as compared with other major groundwater reservoirs samples throughout the country. The relative high-water levels within the aquifers and negative effects of sediments are responsible for the low value of TDS. Total Hardness ranges from 384.35 to $1140 \mathrm{mg} / \mathrm{L}$ and is therefore it is categorized as very hard water according to [29]. No ammonia nitrogen and nitrate nitrogen pollution were detected. Tri-linear diagrams are perhaps the most commonly used technique for finding hydrochemical patterns in major ion data.In the present study, a Piper diagram [26] was used to determine the major hydrochemical facies. It shows that $\mathrm{SO}^{2-}$ and $\mathrm{Ca}^{2+}$ are the main hydrochemical facies in groundwater. Accordingly, two water types were recognized in this region. These are $\mathrm{Cl}-\mathrm{SO} 4-\mathrm{Na}-\mathrm{Ca}$ and $\mathrm{Cl}-\mathrm{SO} 4-\mathrm{Na}$. The first type (Cl -SO4$\mathrm{Na}$ ) belongs to well of Z-1, Z-2, Z-3, Z-4, Z-5, Z-10 and dominate source of this facies comes from dissolution of limestone and marl in the study area. The second type belongs to the wells Z-6, Z-7, Z-8, Z-9. The dominant source for this facies comes from dissolution of limestone, dolomite and calcarenite.

\subsection{Correlation of major chemical indices}

Multiple correlations are useful to interpret the major hydrogeochemical evolution processes within an aquifer and can also be used to deduce the sources of ions and the origin of the groundwater and to measure and establish the relationships between average variables. It also helps to distinguish the relevant hydro geochemistry facias. The multiple diagonally symmetrical linear correlation matrices of $\mathrm{Na}^{+}, \mathrm{K}^{+}, \mathrm{Ca}^{2+}, \mathrm{Mg}^{2+}, \mathrm{HCO}_{3}{ }^{-}, \mathrm{SO}_{4}{ }^{2-}, \mathrm{Cl}^{-}, \mathrm{CO}_{3}{ }^{-}$, $\mathrm{pH}, \mathrm{EC}, \mathrm{TH}$ and TDS of the study area samples are given in (Table. 6). The relation between the variable $\mathrm{Na}+$ vs $\mathrm{K}^{+}$ show positive correlation. The $\mathrm{Na}^{+}$and $\mathrm{K}^{+}$are mainly obtained from the weathering of calc-alkaline group of rocks and carbonate sources are mainly obtained from the per alkaline group of rocks.

The relationship of variables in the study area also shows existing same positive correlation, except $\mathrm{HCO}_{3}{ }^{-}, \mathrm{K}^{+}$and vs $\mathrm{TH}$, which shows a very low degree of insignificant negative correlation. The correlation studies between TDS vs $\mathrm{K}^{+}, \mathrm{Na}^{+}, \mathrm{Ca}^{2+}$ and $\mathrm{Mg}^{2+}$ show positive correlations which indicate that the combined operation of chemical weathering, groundwater movement and controlled the chemistry of groundwater in the study area.

The cluster analyses of geochemical parameters of the study area is performed for ionic concentration on the elements of hydrogeochemistry of groundwater and for classify cases of groups that are relatively heterogeneous between each other, on the basis of a defined set of variables. The cluster analyses have been performed using SPSS software and Ward's method. The average parried groups of ionic clusters of geochemical parameters are $\left(\mathrm{Mg}^{2+}, \mathrm{Ca}^{2+}, \mathrm{SO}^{2-}, \mathrm{CO}^{-}\right),\left(\mathrm{Cl}^{-}, \mathrm{HCO}^{-}, \mathrm{CO}^{-}, \mathrm{TDS}, \mathrm{K}^{+}\right)$, $(\mathrm{pH}, \mathrm{Na}+, \mathrm{EC})$ and $(\mathrm{TH})$ Fig 11. First cluster includes the sample locations of Z-4, Z-5, Z-7 and Z-9. The second cluster consists of the sample locations of Z-6, Z-8, Z-11 and Z-3. The third cluster involves the sample locations such as Z-1, Z-2 and Z-10. The fourth cluster consists of the sample locations of Z-12. 


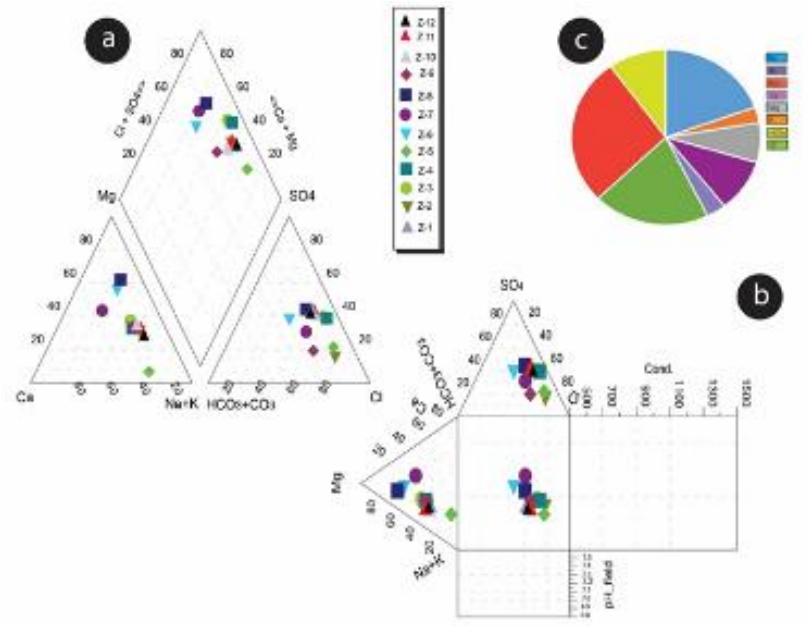

Fig. 11. Trilinear Diagram of the major ions in the groundwater of Azintan area.

\begin{tabular}{lccccccccccccc}
\hline Sample & $\mathrm{pH}$ & $\mathrm{TC}^{\mathrm{o}}$ & $\mathrm{EC}$ & $\mathrm{TDS}$ & $\mathrm{TH}$ & $\mathrm{Na}+$ & $\mathrm{K}+$ & $\mathrm{Mg} 2+$ & $\mathrm{Ca} 2+$ & $\mathrm{Cl}-$ & SO42- & HCO3- & $\mathrm{CO}-$ \\
\hline Z-1 & 7.5 & 22 & 3190 & 1910 & 920 & 409 & 60.8 & 153.52 & 205 & 420 & 426 & 210 & 0 \\
Z-2 & 7.6 & 22 & 3108 & 1860 & 700 & 362 & 58 & 126.7 & 103 & 368 & 521 & 191 & 0 \\
Z-3 & 8.3 & 22 & 2160 & 1296 & 500 & 221 & 52.1 & 78.16 & 71.2 & 250 & 430 & 502 & 4 \\
Z-4 & 7.74 & 22 & 995 & 686 & 384.4 & 118.87 & 56.96 & 37.33 & 92.34 & 262.7 & 153 & 79.09 & 0 \\
Z-5 & 7.67 & 21 & 965 & 676 & 461.2 & 132 & 34 & 44.79 & 110.8 & 213 & 264 & 89.64 & 0 \\
Z-6 & 7.22 & 21 & 2087 & 1461 & 860.9 & 121 & 30 & 89.59 & 196.98 & 568 & 613 & 137.1 & 0 \\
Z-7 & 7.28 & 20 & 1493 & 1060 & 568.8 & 110 & 28 & 63.46 & 123.11 & 298.2 & 525 & 126.5 & 0 \\
Z-8 & 7.2 & 22 & 2006 & 1360 & 953.2 & 105 & 26 & 108.25 & 203.14 & 568 & 575 & 84.36 & 0 \\
Z-9 & 7.9 & 22 & 1498 & 899 & 550 & 75.5 & 20.8 & 99.64 & 55.8 & 220 & 360 & 366 & 4 \\
Z-10 & 7.8 & 22 & 3180 & 1910 & 1140 & 131 & 37 & 155.34 & 200 & 348 & 320 & 321 & 0 \\
Z-11- & 7.8 & 22 & 1857 & 1115 & 920 & 122 & 27.7 & 183.8 & 65.1 & 288 & 450 & 219 & 4 \\
Z-12 & 8.1 & 22 & 3730 & 2240 & 420 & 147 & 29 & 63.47 & 63.4 & 420 & 426 & 210 & 0 \\
average & 7.68 & 21.67 & 2189.08 & 1372.75 & 698.2 & 171.2 & 38.36 & 100.34 & 124.16 & 352 & 421.92 & 211.3 & 1.09 \\
Liby.stand. & 6.5 & - & 750 & $>1000$ & 300 & 200 & 40 & 150 & 200 & 250 & 400 & - & - \\
WHO2017 & - & 1500 & 1500 & $100-500$ & 600 & $10=12$ & $50-100$ & $75-200$ & 500 & 250 & 500 & - & - \\
\hline
\end{tabular}


Table 4 Results of the physiochemical analyses $(\mathrm{mg} / \mathrm{L})$

Table 5. The statistical analysis results.

\begin{tabular}{|c|c|c|c|c|c|c|c|c|c|c|c|c|}
\hline Samples & $\mathrm{Z}-1$ & $\mathrm{Z}-2$ & $\mathrm{Z}-3$ & $\mathrm{Z}-4$ & $\mathrm{Z}-5$ & Z-6 & $\mathrm{Z}-7$ & $\mathrm{Z}-8$ & Z-9 & $\mathrm{Z}-10$ & $\mathrm{Z}-11$ & $\mathrm{Z}-12$ \\
\hline $\begin{array}{l}\mathrm{Na} \% \\
\text { MH(Magnesium }\end{array}$ & 49.38 & 57.42 & 52.31 & 38.91 & 41.05 & 27.65 & 33.89 & 23.73 & 29.99 & 25.03 & 30.61 & 48.54 \\
\hline Hazard \%) & 42.82 & 51.05 & 52.33 & 28.79 & 28.79 & 31.26 & 34.01 & 34.76 & 64.1 & 43.72 & 73.84 & 50.03 \\
\hline SAR $\%$ & 10.8 & 12.48 & 9.04 & 5.22 & 5.29 & 3.57 & 4.03 & 2.98 & 3.03 & 3.47 & 3.87 & 6.53 \\
\hline $\begin{array}{l}\mathrm{Na} /(\mathrm{Na}+\mathrm{Ca}) \\
\mathrm{meq} / \mathrm{L} \\
\mathrm{Cl} /(\mathrm{Cl}+\mathrm{HCO} 3)\end{array}$ & 0.67 & 0.78 & 0.76 & 0.56 & 0.54 & 0.38 & 0.47 & 0.34 & 0.58 & 0.4 & 0.65 & 0.7 \\
\hline meq/L & 0.67 & 0.66 & 0.33 & 0.77 & 0.7 & 0.81 & 0.7 & 0.87 & 0.38 & 0.52 & 0.57 & 0.56 \\
\hline $\mathrm{HCO} 3 \mathrm{meq} / \mathrm{L}$ & 3.44 & 3.13 & 8.23 & 1.3 & 1.47 & 2.25 & 2.07 & 1.38 & 6 & 5.26 & 3.59 & 4.2 \\
\hline $\mathrm{Ca}$ meq/L & 10.25 & 5.15 & 3.56 & 4.62 & 5.54 & 9.85 & 6.16 & 10.16 & 2.79 & 10 & 3.26 & 3.17 \\
\hline $\mathrm{Mg}$ meq/L & 12.64 & 8.84 & 6.43 & 3.07 & 3.69 & 7.37 & 5.22 & 8.91 & 8.2 & 12.79 & 15.13 & 5.22 \\
\hline $\mathrm{Ca}+\mathrm{Mg}$ meq/L & 22.89 & 13.99 & 9.99 & 7.69 & 9.23 & 17.22 & 11.38 & 19.07 & 10.99 & 22.79 & 18.38 & 8.39 \\
\hline $\mathrm{Cl}$ meq/L & 11.86 & 10.4 & 7.06 & 7.42 & 6.02 & 16.05 & 8.42 & 16.05 & 6.21 & 9.83 & 8.14 & 9.15 \\
\hline Na meq/L & 17.78 & 15.74 & 9.61 & 5.17 & 5.74 & 5.26 & 4.78 & 4.57 & 3.28 & 5.7 & 5.3 & 6.39 \\
\hline $\mathrm{SO} 4 \mathrm{meq} / \mathrm{L}$ & 2.66 & 3.26 & 2.69 & 0.96 & 1.65 & 3.83 & 3.28 & 3.59 & 2.25 & 2 & 2.81 & 2.44 \\
\hline
\end{tabular}

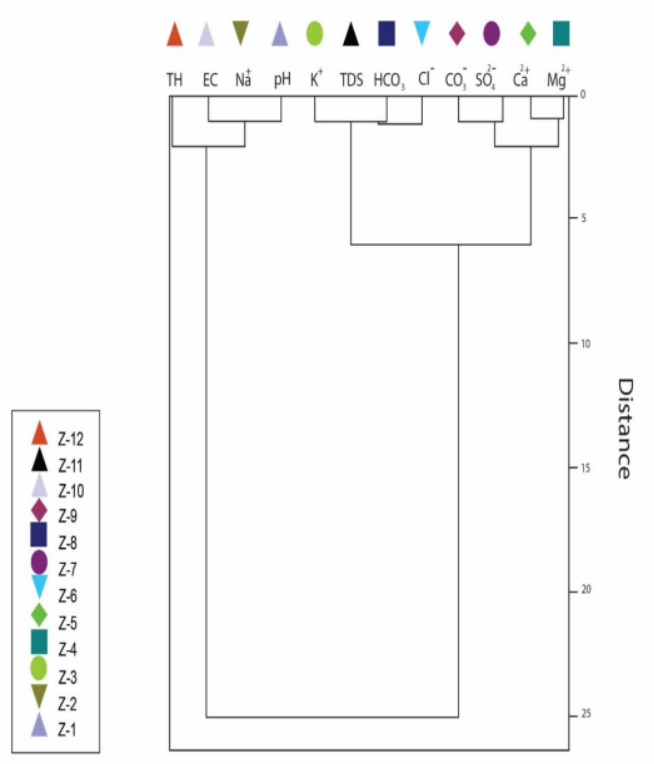

Table 6. The multiple correlation matrix of water quality parameters.

Continue.

\begin{tabular}{rrrrrr}
\hline $3-$ & & EC & & TDS & \multicolumn{2}{c}{ TH } & \\
\hline-0.1 & 1 & & & \\
-0.2 & 0.99 & 1 & & \\
-0.1 & 0.37 & 0.4 & 1 \\
\hline
\end{tabular}

Fig.11 Dendrogram of groundwater aquifers in Zintan. 


\section{International Journal of Engineering Applied Sciences and Technology, 2021 \\ Vol. 6, Issue 5, ISSN No. 2455-2143, Pages 299-304 \\ Published Online September 2021 in IJEAST (http://www.ijeast.com)}

The ratio of $\mathrm{Na}$ and $\mathrm{Cl}^{-}$in meq/L should be equal to 1 , if $\mathrm{Cl}^{-}$and $\mathrm{Na}^{+}$are derived solely from the dissolution of halite. Most samples are plotted below the 1:1 line (Fig. 12a), which indicate that the $\mathrm{Na}+$ is lower than $\mathrm{Cl}$ - content due to the cation exchange makes $\mathrm{Na}+$ in groundwater (Fig. 12a) Furthermore, $\left(\mathrm{Ca}^{2+}+\mathrm{Mg}^{2+}\right)$ versus HCO3- (Fig.12b) plot shows that the samples plotted below 1:1 and 1:2. The content is slightly in excess of $\mathrm{HCO} 3-$ due to role of silicate weathering as the primary mechanism for the occurrence of dissolved salts in the groundwater and indicating that the dissolution of dolomite is likely to occur in the area. In summary, the dissolution of carbonate minerals (calcite and dolomite) may make important contributions to the $\mathrm{Ca}^{2+}, \mathrm{Mg}^{2+}$ and $\mathrm{HCO}^{-}$in groundwater. Similarly, if the dissolution of gypsum is the only explanation to the origin of $\mathrm{Ca}^{2+}$ and $\mathrm{SO}^{2-}$, the ratio of $\mathrm{Ca}^{2+}$ and $\mathrm{SO}_{4}^{2-}$ in meq/L should be $1: 1$ (Fig. 12c). Gypsum is oversaturated in the groundwater, and their dissolution can be a significant contribution to the increasing content of $\mathrm{Ca} 2+$ in the groundwater.

\section{2 luster Analysis}

However, the calcite is saturated, therefore, calcite precipitation is most likely the most appropriate explanation for the $\mathrm{Ca}^{2+}$ deficiency versus $\mathrm{SO}^{2-}$ (Fig. 12c). The slope for $\mathrm{HCO}^{-}$against $\mathrm{Ca} 2+$ should range from 1:1 to 1:2. (Fig.12d).

\begin{tabular}{lllllllll}
\hline 1 & $\mathrm{pH}$ & $\mathrm{Na}^{+}$ & $\mathrm{K}^{+}$ & $\mathrm{Mg}^{2+}$ & $\mathrm{Ca}^{2+}$ & $\mathrm{Cl}^{-}$ & $\mathrm{SO}^{2-}$ & $\mathrm{HCO}_{3}$ \\
\hline $\mathrm{pH}$ & 1 & & & & & &, & \\
$\mathrm{Na}{ }^{+}$ & 0.01 & 1 & & & & & & \\
$\mathrm{~K}^{+}$ & 0.16 & 0.79 & 1 & & & & & \\
$\mathrm{Mg}^{2+}$ & -0.06 & 0.34 & 0.03 & 1 & & & & \\
$\mathrm{Ca}^{2+}$ & -0.69 & 0.19 & 0.09 & 0.29 & 1 & & & \\
$\mathrm{Cl}^{-}$ & -0.58 & 0.11 & -0.11 & 0.20 & 0.694 & 1 & & \\
$\mathrm{SO}_{4}{ }^{2-}$ & -0.48 & 0.14 & -0.27 & 0.29 & 0.329 & 0.68 & 1 & \\
$\mathrm{HCO}_{3}^{-}$ & 0.728 & 0.13 & 0.087 & 0.26 & -0.31 & -0.3 & -0.04 & 1
\end{tabular}
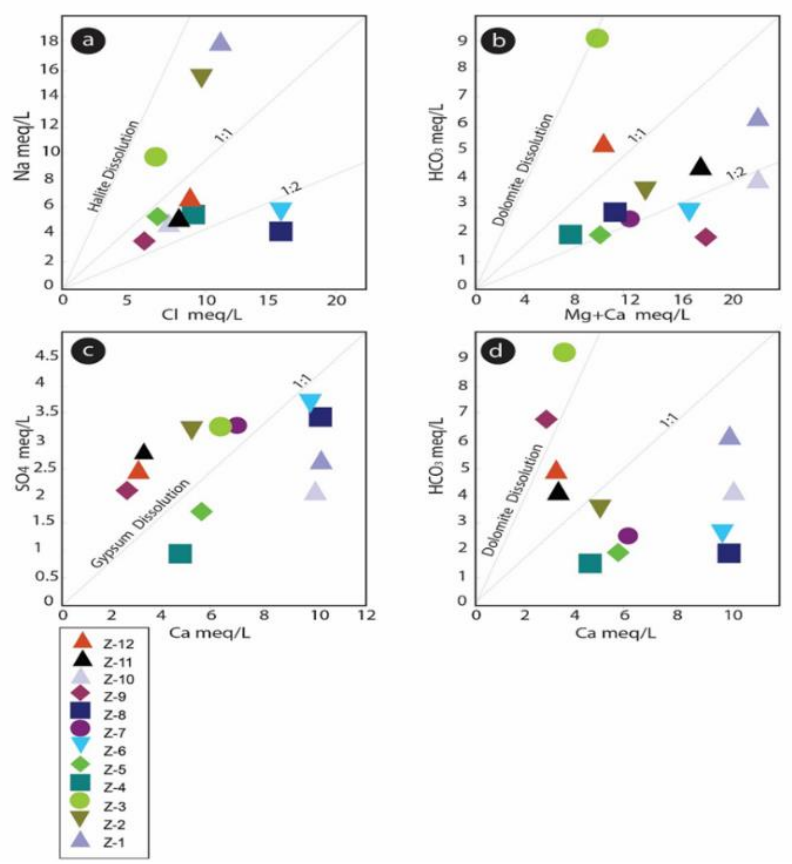

Fig.12. Relationships among major ions in groundwater samples.

\section{DISCUSSION}

The important hydrogeochemical parameters in assessing water quality are TDS, EC and SAR, which reflect the classifications of irrigation and drinking water quality. The values of SAR (Table 5) and EC (Fig.7) show that most groundwater samples belong to the category $\mathrm{C} 3-$ $\mathrm{S} 1$, which is suitable for agricultural purposes. The poor quality of the groundwater is controlled by levels of TDS, $\mathrm{TH}, \mathrm{Cl}-$ and $\mathrm{SO}_{4}^{2-}$, which result from the dissolution of various mineral phases in the aquifer. Sulfate content ranges from 153 to $613 \mathrm{mg} / \mathrm{l}$ with average of $421.92 \mathrm{mg} / \mathrm{L}$. The increment of sulfate toward southern part $>450 \mathrm{mg} / \mathrm{Lis}$ mostly due to dissolution of gypsum minerals. and also, due to extension of gypsiferous limestone. The sulfate ions reached the groundwater system. The percolating water usually dissolves completely all highly salts such as $\mathrm{NaCl}$, but partially dissolve sparingly soluble salt such as gypsum [11]. However, toxicity is rarely a problem, except at very high concentrations, where high sulfate may interfere with uptake of other nutrients. Although chloride is essential to plants amounts, it can cause toxicity to sensitive crops such as fruit and vegetable crops at high concentrations Table 7 [6]. 


\section{International Journal of Engineering Applied Sciences and Technology, 2021 \\ Vol. 6, Issue 5, ISSN No. 2455-2143, Pages 299-304 \\ Published Online September 2021 in IJEAST (http://www.ijeast.com)}

However, in the northern area, the groundwater has EC values between 670 to 2000 as/cm (except sample Z-1 and Z-2), indicating excellent and good to permissible utility for irrigation.

Table 7. Chloride classification of irrigation water.

\begin{tabular}{|c|c|c|}
\hline $\begin{array}{l}\text { Chloride } \\
(\mathrm{mg} / \mathrm{l})\end{array}$ & Effect on crops & Samples \\
\hline$<70$ & $\begin{array}{l}\text { Generally safe for all } \\
\text { plants }\end{array}$ & \\
\hline $70-140$ & $\begin{array}{l}\text { Sensitive plants show } \\
\text { injury }\end{array}$ & \\
\hline $140-350$ & Moderately tolerant plants & $\begin{array}{l}\text { except Z-1,Z-2 Z- } \\
12\end{array}$ \\
\hline$>350$ & $\begin{array}{l}\text { Can cause severe } \\
\text { problems }\end{array}$ & Z-1, Z-2,Z-12 \\
\hline
\end{tabular}

Another indicator that is used to specify the magnesium hazard $(\mathrm{MH})$ as proposed by [31] for irrigation water (Table 8). From the calculated values, the magnesium hazard values range between 28.7 and 73.84 (Table 9). A value of $\mathrm{MH}>50 \%$ indicates harmful groundwater and unsuitable for irrigation, while a value $\mathrm{MH}<50 \%$ indicates suitable groundwater.

Table 8. Sodium hazard classes based on sodium adsorption ratio after [37].

\begin{tabular}{|c|c|c|c|c|}
\hline $\begin{array}{l}\text { Sodium } \\
\text { hazard } \\
\text { class }\end{array}$ & SAR & \multicolumn{2}{|c|}{$\begin{array}{l}\text { Water } \\
\text { class }\end{array}$} & Study samples \\
\hline $\mathrm{S} 1$ & 10 & \multicolumn{2}{|c|}{$\begin{array}{l}\text { Excelle } \\
\text { nt }\end{array}$} & $\begin{array}{l}\text { Z-7, Z-8, Z-9, Z-10, Z- } \\
11, \text { Z-12 }\end{array}$ \\
\hline S2 & $10-18$ & \multicolumn{2}{|c|}{ Good } & $\begin{array}{l}Z-2, Z-4, Z- \\
5\end{array}$ \\
\hline S3 & $18-26$ & \multicolumn{2}{|c|}{$\begin{array}{l}\text { Doubtfu } \\
1\end{array}$} & $\begin{array}{l}\text { Z-1,Z-2,Z- } \\
3\end{array}$ \\
\hline S4 and S5 & $>26$ & \multicolumn{2}{|c|}{$\begin{array}{l}\text { Unsuita } \\
\text { ble }\end{array}$} & \\
\hline \multicolumn{5}{|c|}{$\begin{array}{l}\text { Table 9. Water quality based on magnesium hazard } \\
\text { after [37]. }\end{array}$} \\
\hline $\begin{array}{l}\text { Magnesium } \\
\text { hazard }\end{array}$ & \multicolumn{2}{|l|}{$\begin{array}{l}\text { Water } \\
\text { class }\end{array}$} & \multicolumn{2}{|c|}{ Remark } \\
\hline$<50 \%$ & \multicolumn{2}{|c|}{ Suitable } & \multicolumn{2}{|c|}{$\begin{array}{l}\text { Z-1, Z-4, Z-5, Z-6, Z-7, Z-8, } \\
\text { Z-10 }\end{array}$} \\
\hline$>50 \%$ & \multicolumn{2}{|c|}{$\begin{array}{l}\text { Unsuitabl } \\
\text { e }\end{array}$} & \multicolumn{2}{|c|}{ Z-2, Z-3, Z-9, Z-11, Z-12 } \\
\hline
\end{tabular}




\section{International Journal of Engineering Applied Sciences and Technology, 2021 \\ Vol. 6, Issue 5, ISSN No. 2455-2143, Pages 299-304 \\ Published Online September 2021 in IJEAST (http://www.ijeast.com)}

\section{CONCLUSIONS}

The study area is a terrain which consists of sandstone rocks and crystalline limestone and dolomite and evaporite rocks. Gibbs mechanism reveals evaporation and rock dominance character controlling water chemistry. Geochemical evaluation through Piper analysis shows the predominance by higher concentrations of $\mathrm{Cl}^{-}-\mathrm{SO}^{2-}-\mathrm{HCO}^{-}-\mathrm{Cl}^{-}-\mathrm{SO} 42--$ $\mathrm{Na}+-\mathrm{Ca} 2+$ and $\mathrm{Cl}--\mathrm{SO} 42--\mathrm{Na}+$ rich facies. Groundwater samples generally show within the permissible limit of Libyan standards guidelines and WHO drinking water standard except $\mathrm{pH}, \mathrm{EC}, \mathrm{TH}, \mathrm{SO} 42-$ and $\mathrm{Cl}-$.The majority of samples are suitable for irrigation purposes. Groundwater quality may be enhanced by river basin recharge.

\section{Acknowledgements}

The authors are grateful to Mohammed Balham, the head of Water and Gas Analysis Laboratory of Libyan National Oil Corporation in Az Zawiyah. Many Thanks should also go to everyone at the Engineering Faculty Lab. in Sabratha for attaining the analysis of the samples.

\section{REFERENCES}

[1] Alexakis, D., (2011). Assessment of water quality in the Messolonghi-Etoliko and Neochorio region (west Greece) using hydrogeochemical and statistical analysis methods. Environmental monitoring and assessment 182,(pp.397-413).

[2] Anzecc, (1992). Western Australia water quality guidelines for fresh and marine water. Report of environmental protection authority. Perth, Western Australia, Bulletin 711.

[3] Aral M., and Warren S., (2011). Groundwater quality and quality management, American Society of Civil Engineers. ISBN, 978-0-7844-1176-6.

[4] Banks. F, and Siewers U., (2001). The chemistry of Norwegian groundwater. IV. The $\mathrm{pH}$-dependence of element concentrations in crystalline bedrock groundwater. Science of Total Environment 227, (pp.101-117).

[5] Basavaraddi, S.B., Kouser H., Puttaiah E.T., (2012). Sodium toxicity in groundwater and its hazardous effect on life-A study in Tipture Town and its surrounding areas, Global advanced research. Journal of Microbiology 1(9), (pp.149-154).
[6] Bauder T.A., Waskom R.M., Sutherland P.L., Davis J.G. (2011): Irrigation Water Quality Criteria, Fact Sheet No. 0.506 , Colorado State University.

. Christie A., (1955). Geology of Gharyan Area, Tripolitania, Libya. Ministry of Industry, Geological section, Bulletin No.5.

[7] Brika, B. (2018). Proceedings of the 3EWaS International Conference on Insights on the Water-Energy-Food Nexus, Lefkada Island, Greece. 27-30.

[8] Burollet P., ( 1963). Field trip guide book of the excursion to jebel Nafusah Saharan Symp. Tripoli. Petroleum exploration society of Libya.( pp. 17).

[9] CEDARE, (2014).Libya Water Sector M\&E Rapid Assessment Report. Monitoring and Evaluation for Water in North Africa (MEWINA) project, Water Resources Management Program, CEDARE.

[10] Danielopol, D., Griebeler, C., Gunatilaka A., Noteboom J. (2003). Present state and future prospects for groundwater ecosystes. Environmental Conservation 30 (2), (104-130).

[11] Drever, J. I. (1982). The geochemistry of natural waters. Prentice-Hall, Inc., Englewood Cliffs, N.J.(pp. 388).

[12] Desio A., Rossi C., Pozzi R., Clerici F., Invernizzi G., Pisoni C., Vigano P. 1963. Stratigraphic studies in the Tripolitania Jebel. Riv. ital. Paleont. Mem. IX, (pp 126).

[13] General Water Authority, (1999). National Strategy for Integrated Water Resources Management (2000-2025).

[14] Gibbs, R., J. 1970. Mechanisms controlling World water chemistry. Science 170,(pp.1088-09).

Hamouda, O., S., (1969). Jurassic and Lower Cretaceous Rocks of Central Jebel Nefusah, Norhwestern Libya. Petroleum Exploration Society of Libya, Tripoli, (pp. 1- 65).

[15] Keller W. 1978. Drinking water; A geochemical factor in human health. Geological society of America. Bulletin 89(3),(pp.334-336).

[16] Kortatsi B. (2007). Hydrochemical framework of groundwater in the Ankobra Basin, Ghana. Aquatic Geochemistry 1,(pp. 41-74).

[17] Kruseman G., P. and Floegel H. (1980). In M. J. Salem and M.T. Busrewil (editors). Geology of Libya.Vol.II.Academic press. London ( pp. 763-755). 


\section{International Journal of Engineering Applied Sciences and Technology, 2021 \\ Vol. 6, Issue 5, ISSN No. 2455-2143, Pages 299-304 \\ Published Online September 2021 in IJEAST (http://www.ijeast.com)}

[18] Kumaresan, M. and Riyazuddin, P. (2006). Major ion chemistry of environmental samples around sub-urban of Chennai city. Journal of Current Science 91(12), (pp. 16681677).

[19] Lexique stratigraphique international. ( 1960). Vol. IVAfrique. Fasc. Iva-Libyie.

[20] Azintan weather station, 2020. Annual report.

[21] Libyan national center for specifications and standards (1992). Drinking water standards. Bulletin 82.

[22] Libyan National Meteotological Center. 2017. 2017 annual report.

Tripoli Libya.

[23] Mattess, G. (1982). The properties of groundwater. John Wiley, New YORK.p406.

[24] Magnier, Ph. (1963). Etude stratigraphique dans le Gebel Nefousa et al Gebel Garian. Bulletin Society Geology of France 5(7), (pp.89-94).

[25] Parkhurst, D., and Appelo, C., (1999). User's guide to PHREEQC. Computer program. U.S. Geological Survey Water Resources investigations report., (pp.99-4259).

[26] Piper, A. M. (1953). A Graphic Procedure in the Geochemical Interpretation of Water Analysis. Washington D.C. United States Geological Survey.

[27] Rao, S.( 2006). Seasonal variation of groundwater quality in a part of Guntur District .Andhra pradesh, India. Environmental Geology 49,(pp.413-429).

[28] Saleh A., and Shehata M.,( 1999). Arid Environments 42,(pp.195-209).

[29] Sawyer GN, McCarthy DL, (1967). Chemistry of sanitary Engineer, 2nd Ed, McGraw Hill, New York. (pp. $518)$.

[30] Subramani, T., Elango, L., Dhamodarasamy, S. (2005). Environmental Geology 47,(pp.1099-1110).

[31] Szabolcs, I. and Darab, C. (1964). The Influence of Irrigation Water of High Sodium Carbonate Content of Soils. Proceedings of 8 th International Congress of ISSS, Trans. (2). (pp.803-812).
U.S. Public health service (1975). Drinking water Standards. Publication No.969.

[32] U.S Salinity laboratory (1980). Diagnosis and improvement of saline and alkaline soils. Department of Agriculture, handbook 60,(pp.160).

[33] USSL (United States Salinity Laboratory Staff) 1954. Diagnosis and Improvement of Saline and Alkali Soils. US Department of Agriculture (USDA), Agriculture Handbook 60, Washington, (pp.69-81).

[34] World Health Organization (WHO) (2017). Guidelines for drinking water quality, Library Cataloguing-inPublication Data, 4th ed. classification: WA 675. Geneva, World Health Organization.

[35] World Health Organization (WHO) (1989). Guidelines to drinking water quality. Geneva 186

[36] WHO 1983. Health guidelines for use of wastewater in agriculture and aquaculture. World Health Organization, Geneva, (pp.778. 74).

[37] Wilcox, L. V. (1995). Classification and use of irrigation waters, US Department of Agriculture, Washington DC, (pp. 19). 